African Journal of Biomedical Research, Vol. 10 (2007); 139 - 143

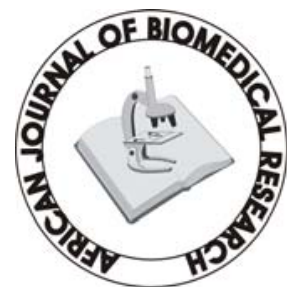

Full-text available at http://www.ajbrui.com http://www.bioline.br/md http://www.ajol.com

Received:

November 2006

Accepted February 2007

Published

May 2007
Full Length Research Article

\section{The Effect of Chronic Cement Dust Exposure on Lung Function of Cement Factory Workers in Sokoto, Nigeria}

\author{
${ }^{1}$ Merenu I.A., ${ }^{2 *}$ Mojiminiyi F.B.O., ${ }^{3}$ Njoku C.H., ${ }^{4}$ Ibrahim M.T.O. \\ Specialist Hospital ${ }^{1}$, Sokoto, Nigeria \\ Departments of Physiology ${ }^{2}$, Medicine $e^{3}$ and Community Health ${ }^{4}$, \\ College of Health Sciences, Usman Danfodio \\ University, P.M.B. 2254, Sokoto, Nigeria.
}

\section{ABSTRACT}

The present study was designed to investigate the effect of cement dust exposure on lung function in Nigerians because of paucity of such data. Lung function tests were carried out on 56 cement factory workers with mean years of exposure to cement dust of 10.2 \pm 5.6 years and on 96 non exposed subjects. The vital capacity (3.7 \pm 0.5 ; versus $4.1 \pm 0.5 \mathrm{~L} ; \mathrm{P}<0.001)$ and forced expiratory volume in one second percent $\left(F E V_{1} \%\right.$; $78.4 \pm 13.8$; versus $89.0 \pm 6.9$; $\left.P<0.005\right)$ were significantly lower in cement factory workers than in control subjects. However, forced vital capacity (3.9 \pm 0.1 versus $4.0 \pm 0.1 L)$ and Peak Expiratory Flow Rate (PEFR; $497.0 \pm 14.0$ versus $527 \pm 15.0 \mathrm{~L} / \mathrm{min}$ ) showed no significant difference. These results suggest that chronic cement dust exposure impairs lung function. Since protective gears were available, these findings suggest that either compliance to their use was poor or they were ineffective. It is recommended that the cement factory management embark on health education, acquire effective protective gadgets and enforce their usage. Also there should be containment of dust emission by use of dust filters.

(Afr. J. Biomed. Res. 10: 139 - 143

Keywords: Lung function, Cement dust, exposure, Sokoto, Nigeria

*Address for Correspondence: mojiminiyi@yahoo.co.uk

Abstracted by:

African Index Medicus (WHO), CAB Abstracts, Index Copernicus, Global Health Abstracts, Asian Science Index, Index Veterinarius, Bioline International , African Journals online 


\section{INTRODUCTION}

Cement production is invariably a dusty operation resulting in the exposure of factory workers to cement dust. Although protective gears should be worn, reports from third world countries indicate that industries rarely provide precautionary measures (Al-Neaimi et al, 2001; Azah et al, 2002). The resulting exposure to cement dust has led to impairment of respiration and a prevalence of respiratory symptoms amongst workers (Alakija et al, 1990; Al-Neaimi et al, 2001; Meo et al, 2002) culminating in what has been described as a "Cement factory lung disease” (Alakija et al, 1990). The severity of the impairment of respiratory function has been shown to depend on years of exposure (Alakija et al, 1990).

However there are reports that contradict this notion (Vestbo and Rasmussen, 1990; Yang et al, 1993; Fell et al, 2003). These reports suggest that cement dust exposure may neither increase the morbidity of respiratory diseases (Vestbo and Rasmussen, 1990; Fell et al, 2003) nor be associated with the prevalence of respiratory symptoms among workers (Yang et al, 1993; Fell et al, 2003).

The parameters used to assess respiratory function in these studies include vital capacity, $\mathrm{FEV}_{1}$ (Forced expiratory volume in 1 second) $\mathrm{FEV}_{1} \%$ (Forced expiratory volume in 1 second as a percentage of forced vital capacity), and PEFR (Peak expiratory flow rate) (Alakija et al, 1990; AlNeaimi et al, 2001; Meo et al, 2002). There are few reports on the effect of cement dust exposure in cement factory workers in Nigeria. To our knowledge only one study has addressed this problem at the Cement factory, Okpella, Edo State (Alakija et al, 1990). A related work on the effect of granite dust exposure on lung function of children schooling near the Crushed rock industry, Akamkpa, Cross River State has also been reported (Azah et al, 2002). In this report we have studied lung function in cement factory workers in Sokoto. This study was embarked upon in view of the controversy concerning the effect of cement dust exposure on lung function and the paucity of such data in Nigeria.

\section{MATERIALS AND METHODS}

The study population comprised those working in the cranes, packing, crusher and mill sections of the factory. The workers in these sections were selected because of their high level of exposure (Alakija et al, 1990; Mwaiselage et al, 2005). All the 56 eligible workers of the total number of 70, working in these sections were enrolled in the study. They had been exposed to cement dust for a period of $10.2 \pm 5.6$ (mean \pm SEM) years. An unexposed (control) group consisted of 96 blue-collar workers who belonged to the same socio-economic class as the exposed group, and working and residing 20 kilometers away from the cement factory in the Sokoto metropolis. Only subjects who were non smokers and who had no history or signs of chronic cough, bronchitis, bronchial asthma or other signs and symptoms suggestive of respiratory diseases were eligible and selected into both the exposed and unexposed groups.

Data collection was effected by way of an interviewer-administered structured questionnaire, to determine the socio-demographic characteristics, years of exposure as deduced from date of employment, site or position at workplace, use of safety gadgets such as dust masks, earplugs, hand gloves, safety boots, goggles and work overalls. Information on general health, history of past disease(s) and habits such as smoking and alcohol consumption were obtained.

The heights $(\mathrm{cm})$ of the subjects were measured without shoes. Weight $(\mathrm{kg})$ was measured with minimum clothing using a bathroom scale. Lung function tests were carried out with a vitalograph spirometer (Vitalograph Ltd, Buckingham, UK) and a Wright peak flow meter (Airmed, UK). The procedures were carefully explained and demonstrated to each subject and then the tests were carried out. Each anthropometric or lung function parameter was measured by a trained technician familiar with the procedure. The use of one observer per measurement was maintained throughout the study. The leader of the team randomly repeated some of the measurements to validate their accuracy.

Vital capacity, forced vital capacity, forced expiratory volume in 1 second, and forced expiratory volume in 1 second percent (as a percentage of forced vital capacity) were measured using a vitalograph spirometer. The recording was done with each subject standing, without nose clips 
and with the lips firmly applied around the disposable mouthpiece. The subject inspired maximally and then expired as forcefully and rapidly as possible into the vitalograph. Three attempts were made and the best of the three spirogram was selected (Afolabi et al, 1996; Al-Neaimi et al, 2001). The value of VC, FVC, and FEV 1 was read off the selected spirogram.

The Peak expiratory flow rate [PEFR], was measured with the subject standing, without nose clips and with lips firmly applied around the disposable mouthpiece. The subject inspired maximally and then expired as forcefully and rapidly into the peak flow meter as possible. The best of three readings was taken (Afolabi et al, 1996; AlNeaimi et al, 2001).

All the lung function parameters were measured at ATPS (ambient temperature and pressure saturated with water vapour). The relationship between vital capacity and years of service at employment was subjected to correlation analysis and a regression equation defining the relationship was derived.

It is well known that anthropometric parameters such as age, sex, height, weight and ethnicity affect lung function (Onadeko et al, 1984; Jaja, 1989; Njoku and Anah, 1999). Attempts were therefore made to match the exposed subjects with the unexposed subjects $a b$ initio. However this was not very successful and so this comparison was designated "Subjects unmatched". To fully achieve matching a subset of subjects from each group $(n=20)$ that matched very well in terms of age, sex, height, weight and ethnicity were selected and this comparison was designated "Subjects matched".

Results are expressed as mean \pm standard error of mean (SEM). Statistical analysis was carried out using the unpaired student $t$ test.

\section{RESULTS}

Table 1 gives a summary of the anthropometric parameters of the exposed and unexposed subjects when they were unmatched and when matched. In the unmatched category, comparison of the anthropometric parameters of the exposed with the unexposed group was similar except in their weights.

Table1. Anthropometric parameters and length of service of workers exposed to cement dust and those unexposed (NS=not significant)

\begin{tabular}{lllllll}
\hline Parameter & \multicolumn{2}{l}{ Subjects Unmatched } & \multicolumn{3}{l}{ Subjects Matched } \\
\cline { 2 - 7 } & $\begin{array}{l}\text { Exposed } \\
\text { (Mean } \pm \text { SEM) }\end{array}$ & $\begin{array}{l}\text { Unexposed } \\
(\text { Mean } \pm \text { SEM) }\end{array}$ & P value & $\begin{array}{l}\text { Exposed } \\
\text { (Mean } \pm \text { SEM) }\end{array}$ & $\begin{array}{l}\text { Unexposed } \\
(\text { Mean } \pm \text { SEM) }\end{array}$ & P value \\
\hline Age [years] & $36.1 \pm 1.7$ & $37.0 \pm 0.8$ & NS & $33.5 \pm 1.0$ & $34.0 \pm 1.0$ & NS \\
\hline Weight [kg] & $67.2 \pm 2.8$ & $61.0 \pm 0.9$ & $<0.001$ & $60.6 \pm 1.4$ & $60.4 \pm 1.2$ & NS \\
\hline Height $[\mathrm{cm}]$ & $173.7 \pm 3.3$ & $174.0 \pm 0.6$ & NS & $171.8 \pm 1.6$ & $172.5 \pm 1.0$ & NS \\
\hline $\mathrm{N}$ & 56 & 96 & & 20 & 20 & \\
\hline
\end{tabular}

Table 2: Lung function parameters of workers exposed to cement dust and those unexposed.

\begin{tabular}{|c|c|c|c|c|c|c|}
\hline \multirow[b]{2}{*}{ PARAMETER } & \multicolumn{3}{|c|}{ Subjects Unmatched } & \multicolumn{3}{|c|}{ Subjects Matched } \\
\hline & $\begin{array}{l}\text { Exposed } \\
{[\text { Mean } \pm \text { SEM] }}\end{array}$ & $\begin{array}{l}\text { Unexposed } \\
\text { (Mean } \pm \text { SEM) }\end{array}$ & P-value & $\begin{array}{l}\text { Exposed } \\
\text { (mean } \pm \text { SEM) }\end{array}$ & $\begin{array}{l}\text { Unexposed } \\
(\text { mean } \pm \text { SEM) }\end{array}$ & P-value \\
\hline Vital capacity [L] & $3.8 \pm 0.09$ & $3.8 \pm 0.07$ & NS & $3.7 \pm 0.1$ & $4.1 \pm 0.5$ & $<0.001$ \\
\hline FVC [L] & $4.0 \pm 0.09$ & $3.8 \pm 0.09$ & NS & $3.9 \pm 0.1$ & $4.0 \pm 0.1$ & NS \\
\hline $\mathrm{FEV}_{1} \%$ & $78.8 \pm 1.8$ & $81.4 \pm 1.6$ & NS & $78.4 \pm 3.1$ & $89.0 \pm 1.5$ & $<0.005$ \\
\hline PEFR [l/min] & $517.1 \pm 10.5$ & $521.4 \pm 8.5$ & NS & $497.0 \pm 14.0$ & $527 \pm 15.0$ & NS \\
\hline $\mathrm{N}$ & 56 & 96 & & 20 & 20 & \\
\hline
\end{tabular}


The exposed group was significantly heavier than the unexposed $(\mathrm{P}<0.001)$. When the subjects were fully matched the anthropometric parameters of both groups were identical.

The lung function parameters are presented in table 2 . These parameters did not differ significantly between the exposed and unexposed groups when the subjects were unmatched. Following the matching of the subjects, the vital capacity $(\mathrm{P}<0.001)$ and $\mathrm{FEV}_{1} \%(\mathrm{P}<0.005)$ fell significantly in the exposed group compared to the unexposed while the forced vital capacity and the peak expiratory flow rate (PEFR) did not differ significantly.

\section{DISCUSSION}

The major finding of this work is that the lung function parameters, vital capacity and $\mathrm{FEV}_{1} \%$, were significantly lower in workers exposed to cement dust compared to those unexposed. This suggests that chronic cement dust exposure impairs lung function. It agrees with the findings of Alakija et al (1990) who first reported "Cement factory lung disease" in Nigeria and those of others elsewhere (Al-Neaimi et al, 2001; Meo et al, 2002). However the forced vital capacity (FVC) and PEFR did not differ significantly in the exposed group compared to the unexposed. This underscores the importance of using several indices of lung function in comparative studies such as this.

However, the present findings do not support the notion that chronic cement dust exposure does not impair lung function as reported by some workers (Vestbo and Rasmussen, 1990; Yang et al, 1993; Fell et al, 2003). In this study, responses from the questionnaires and interview of the workers indicate that protective measures were provided and that they were used. Thus the observed impaired lung function may be due to the ineffectiveness of the protective gears. However non compliance of the workers in the use of protective gears cannot be ruled out in spite of contrary questionnaire and interview responses. Thus, lung function tests may be useful in assessing the effectiveness of preventive measures such as the wearing of dust masks or compliance by workers to preventive measures. Unlike previous reports which indicate the non provision of protective gears in cement (Al-Neaimi et al, 2001) and related factories (Azah et al, 2002) in the developing world, the findings of the present study indicate they were provided.

The lung function parameters showed no significant difference between the exposed and unexposed groups when the subjects were unmatched. This may be due to the fact that the exposed group was significantly heavier than the unexposed although they remained similar in terms of age and height (table 1). When complete matching using weight, age and height was done, the lung function parameters (Vital capacity and $\mathrm{FEV}_{1} \%$ ) became less in the exposed group compared to the unexposed and the effect of cement dust exposure became apparent. This underscores the importance of matching subjects using anthropometric parameters in lung function studies. It also confirms the well known effect of anthropometric parameters on lung function (Onadeko et al, 1984; Jaja, 1989; Njoku and Anah, 1999). The impairment of lung function observed in the exposed group may not be due to socioeconomic factors as both groups came from the same socio-economic class.

The findings of various workers on the various lung function parameters however have varied. For instance, in the work of Alakija et al (1990) $\mathrm{FEV}_{1}$ and PEFR were significantly lower in cement factory workers than in the control group. Also Azah and colleagues (2002) found FVC, FEV and PEFR to be lower in granite dust exposed subjects than in the control group but $\mathrm{FEV}_{1} \%$ remained unchanged. In the present study, vital capacity and $\mathrm{FEV}_{1} \%$ were significantly lower in the cement factory workers than in the unexposed (control) group while the FVC and PEFR remained similar.

The results of the present study suggest that chronic exposure to cement dust has deleterious effect on the lungs. However the exact mechanism (s) by which it does this is unknown. For instance it is yet to be determined whether these effects are due directly to cement dust or mediated by a metabolic product of cement dust. It will be interesting to further investigate this. However it has been suggested that the reduced $\mathrm{FEV}_{1} \%$ in cement factory workers may be due to reflex bronchospasm triggered by inhaled irritant cement dust or as a result of type 1 hypersensitivity reaction (Alakija et 
al, 1990). Indeed the components of cement dust show irritating, sensitizing and pneumoconiotic properties (Maviejewska and Bielichowska-Cybula, 1991). Animal studies reveal that cement dust induces atrophic and hypertrophic changes in the nasal and pharyngeal mucosa as well as chronic exfoliative bronchitis (Maviejewska and Bielichowska-Cybula, 1991). Post mortem examination of the lungs of experimental animals exposed to cement dust revealed slight tissue fibrosis and some emphysema foci (Maviejewska and Bielichowska-Cybula, 1991). Also a report suggests that cement dust exposure may decrease lung and thoracic compliance by impairing intercostal muscle performance (Meo et al, 2002). These effects of cement dust may account for the observed impairment of lung function observed in this study.

In summary, the present results show that the vital capacity and $\mathrm{FEV}_{1} \%$ were significantly reduced in workers exposed to cement dust relative to the unexposed control. However FVC and PEFR remained similar in both groups. These results suggest that chronic exposure to cement dust impairs lung function. Since protective gears were provided, the impaired lung function suggests that the gears were either ineffective or the workers did not use them. It is concluded that chronic exposure to cement dust has adverse effect on lung function. We recommend that to safeguard the health of workers and the host community the cement factory management embark on safety training in work environment and conduct health education on hazards of exposure to cement dust, safety precautions and practices. They should acquire effective protective gadgets and ensure compliance with their usage. Also there should be regular/periodic monitoring of cement dust level in and around the factory environment, and containment of dust emission by the use of dust filters.

\section{ACKNOWLEDGEMENTS}

We are grateful to Mr. M.B. AbdulRahman and Mr. I.U. Alex of the Physiology Department, C.H.S. Usman Danfodio University for technical assistance.

\section{REFERENCES}

Afolabi BM, Ibrahim MM, Ekanem EE. (1996): Pathological indices of occupational exposure at a petrochemical industry in Nigeria: a preliminary study. Afr J Med med Sci. 25, 171-177.

Alakija W, Iyawe VI, Jarikre LN, Chiwuzie JC. (1990): Ventilatory function of workers at Okpella cement factory in Nigeria. West Afr.J Med. 9, 187-192.

Al-Neaimi YI, Gomes J, Lloyd OL (2001): Respiratory illnesses and ventilatory function among workers at a cement factory in a rapidly developing country. Occup Med 2001; 51 (6):367-373.

Azah N, Antai AB, Peters EJ, Osim EE (2002): Effect of exposure to dust generated from crushing of granite rocks on the lung function of southeastern Nigerian children. Nig J Physiol Sci. 2002; 7(1-2): 42 - 47.

Fell AK, Thomassen TR, Kristensen P, Egeland T, Kongerud J (2003):. Respiratory symptoms and ventilatory function in workers exposed to Portland cement dust. J Occup Environ Med. 2003 Sep; 45(9): 1008-1014.

Jaja S.I. (1989): Ventilatory function in adult Nigerians. Nig. J. Physiol. Sci. 1989; 5(2): 96-101.

Maviejewska A, Bielichowska-Cybula G (1991):. Biological effect of cement dust. Med. Pr. 1991; 42 (4): 281-289.

Meo SA, Azeem MA, Ghori MG, Subhan MM (2002):. Lung function and surface electromyography of intercostal muscles in cement mill workers. Int J Occup Med Environ Health. 2002; 15(3): 279-287.

Mwaiselage J, Bratveit M, Moen B, Yost M. (2005): Variability in dust exposure in a cement factory in Tanzania. Ann Occup Hyg. 2005 Aug; 49(6): 511-519.

Njoku CH, Anah CO (1999):. A new formula for predicting peak expiratory flow rate in adult Nigerians. Sahel Med J. 1999; 2(1): 39-44.

Onadeko B.O., Iyun A.O., Sofowora E.O., Adamu S.O. (1984): Peak Expiratory Flow Rate in normal Nigerian children. Afr. J. Med. med. Sci. 1984; 13: 25-32.

Vestbo J, Rasmussen FV (1990):. Long-term exposure to cement dust and later hospitalization due to respiratory disease. Int Arch Occup Environ Health 1990; 62: 217220.

Yang CY, Huang CC, Chang IC, Lee CH, Tsai JT, Ko YC (1993):. Pulmonary function and respiratory symptoms of Portland cement workers in Southern Taiwan. Kao Hsing I Hsueh Ko Hsueh Tsa Chih 1993; 9: 186-192 